\title{
Effect of Naphthalene Acetic Acid (NAA) Spray on Yield and Fruit Characteristics of Zaghloul Date Palm
}

\author{
Abd El-Kader A. M., F.B. El-Makhtoun,Hoda, S.H. Aly and K.A. El-Roby ${ }^{1}$
}

\begin{abstract}
The experiment was carried out through 2005 and 2006 seasons on "Zaghloul" date palm of about 50 years old grown in loamy soil at El-Kanater Horticulture Research Station, Kalubia Governorate, Egypt.

The effect of NAA at $(20,30,40$ and $50 \mathrm{ppm})$ were sprayed on bunches, within two weeks after pollination time, in each season.

Results indicated that NAA spray at different concentrations tended to decrease bunch weight than the control due to reducing fruit number/bunch as a result of fruit drop.

Fruit and flesh weights, fruit dimensions, total soluble solids, sugar content were significantly higher under all treatments. While the acidity content and tannins in fruits were significantly lower in comparison with control. From the present study at is conducted that spraying NAA at 40 or 50 ppm on "Zaghloul" date bunches after two weeks from pollination time was a beneficial treatment to ensure fruit thinning and improve fruit quality under such conditions.
\end{abstract} yield.

Key words: Thinning, NAA, date palm, fruit quality,

\section{INTRODUCTION}

Zaghloul date palm is the most important cultivar of soft dates in Egypt. The fruit is consumed fresh at Khalal stage (red color).

Flower or fruit thinning is a critical cultural practice in the date palm production chain that affects fruit development, quality and yield and regulates tree yearly bearing. Fruit thinning of dates was found to insure adequate flowering the following year, to insure larger size and improve fruit quality and to lighten insure bunch and make it less compact and easier to handle (Bakr et al., 2007 and Hussien et al., 1979). Several methods were used to thin date palm namely: bunch thinning, bunch strands thinning, and individual fruit removal Abou-Rawash and Moustafa (2007), Ali Dinar et al., (2002), Al-Obeed et al., (2003), Bakr et al., (2007) and Moustafa et al., (1993).

Recent investigations have shown that many advances could be achieved in improving yield and fruit quality by the use of certain plant growth regulators for thinning date palm fruits and NAA was reported to be an effective thinner for date palm fruits. (Abou Rawash and Moustafa, 2007; Ali Dinar et al., 2002; Aljuburi et al., 2003; Al-Obeed, 2003; Al-Saikhan, 2008; Bakr et al., 2007; Hussien et al., 1986; Moustafa et al., 1993; and Tavakkoli et al., 2006 on some date palm cultivars.

This investigation was carried out to study the effect of post-pollination application of NAA on fruit characteristics and yield per bunch of Zaghloul date cultivar.

\section{MATERIALS AND METHODS}

This study was carried out in 2005 and 2006 seasons on Zaghloul date palm trees of about 50 years old grown in loamy soil at El-Kanater Al-Khairia Research station, Kalubia Governorate, Egypt. All palm trees were uniform in size and vigor and subjected to the same cultural practices. Pollen grains from the same male palm were used for pollination in both seasons. Only ten similar bunches were left on each female palm. Each bunch contained the same number of strands on every individual palm tree.

Five treatments of NAA were applied to comparable bunches on the same palm within 2 weeks after pollination.

The Naphthalene Acetic Acid (NAA) was sprayed at concentrations of 20,30, 40 and $50 \mathrm{ppm}$ using two bunches for each and two bunches on each palm was sprayed with distilled water and served as a control. The treatments were replicated on four palm trees, Triton B $(0.1 \%)$ was used as wetting agent in all spraying solution and spraying was done in morning with a hand sprayer.

All fruit bunches were harvested (at Khalal stage) on mid of September and bunch weight of each treatment was recorded. Thirty fruits were taken at random from each replicate for the determination of fruit and flesh weights, dimensions of fruit, total soluble solids by hand refractometer as described by A.O.A.C (1995), acidity as a malic acid as described by A.O.A.C (1995), dry matter content, tannins content using the method of Winton and Winton (1958) and sugar contents using method of Forse, (1938) and Smith et al., (1956). The obtained data were statistically analysis according to Snedecor and Cochran (1980).

\footnotetext{
${ }^{1}$ Hort. Res. Institute, Agric. Center, Egypt.

E-mail: hoda_saad23@yahoo.com

Received December21, 2008, Accepted December 29, 2008
} 


\section{RESULTS AND DISCUSSION}

\section{Fruit drop percentage:}

It can be noticed (Table 1 and 2) that NAA significantly increased the percentage of abscised fruits and this effect was dependent on its concentration. Fruit drop percentage was $33.80,37.37,38.12,40.53$ and 31.58 when bunches were treated with $20,30,40,50$ ppm and control, respectively in 2005 season. The corresponding values for 2006 season were 25.75 , $27.32,30.35,34.42$ and 23.48 , respectively. In this respect, NAA treatment at $20 \mathrm{ppm}$, was similar statistically to control bunches in both seasons. Similar trend was obtained by El-Hammady et al., (1983) and Khalifa et al., (1984) on different date palm cultivars.

\section{Yield per bunch:}

NAA treatments significantly decreased the average weight of bunches than the control. The lowest bunch weight was obtained at concentrations of 40 and $50 \mathrm{ppm}$ than bunches treated with $20 \mathrm{ppm}$ and control in both seasons of study. This result might be due to the thinning effect of NAA on date fruits. Several studies have demonstrated that less date fruits in proper managed trees have always better chances to increase size, weight and other fruit quality variables (ElHammady et al., 1983). This is mainly due to abundance of photosynthesis to remaining fruits (Ali-Dinar et al., 2002). NAA was reported to be an effective thinner for date palm fruits (El-Kassas, 1986). These results were identical to those of Tavakkoli et al. (2006) on Shahani date cultivar, because developing fruits normally act as stone sink to tree nutrient sources.

\section{Fruit weight:}

Fruit weight was significantly increased by NAA at 40 and $50 \mathrm{ppm}$ treatments than control in both two seasons. While, NAA at $20 \mathrm{ppm}$ did not induce any significant difference as compared to untreated bunches in both seasons. The fruit weight increment by NAA treatments was induced as a result of diminishes the fruit set percentage. Similar results were found by Aljuburi $e t$ al. (2007); Bakr et al., (2007); Al-Obeed et al., (2003); El-Kassas, (1986), they all reported that NAA was found to be adequate date fruit thinner.

\section{Flesh weight:}

NAA at 40 and $50 \mathrm{ppm}$ treatments significantly increased the flesh weight than control during both seasons. On the other hand, NAA at $20 \mathrm{ppm}$ did not induce any significant differences compared to untreated bunches in both seasons. Mean date fresh fruit weight, flesh percent increased with thinning treatments, AlSaikhan (2008). Similar results were reported by (AboRowash and Moustafa et al., 2007; Bakr et al., 2007; ElKassas, 1986; Moustafa et al., 1993).

\section{Fruit dimensions:}

The fruit length and width were increased by NAA treatments at 30, 40 and $50 \mathrm{ppm}$ than the untreated fruits in both seasons and the differences were significant in most treases. These results were in line with those obtained by (Abd El-Ghaffar and Ceif El-Rahman, 1986; Aljuburi et al., 2007; Al-Obeed et al., 2003; Bakr, et al., 2007 and El-Kassas, 1986).

\section{Dry matter content:}

Dry matter content of fruits treated with NAA at 50 ppm was significantly lower as compared with fruits treated with 20,30 ppm and control in the first season. On the other hand, no significant differences were obtained during the second season by the studied treatments.

\section{Total Soluble Solids:}

NAA treatments had significantly effect on T.S.S. percentage of date fruits (Table 1 and 2). Significant higher of T.S.S. content was observed in fruit treated with NAA at 40 and $50 \mathrm{ppm}$ than the untreated fruits in both seasons. On the other hand, T.S.S. content has nearly similar trends in fruits treated with NAA at 20, 30 ppm and untreated fruits (control) in both seasons. These results were in agreement with results obtained by AboRawash and Moustafa (2007) and Al-Obeed et al., (2007) on different date palm cultivars.

\section{Total Sugars:}

Total sugars content significantly increased in fruits treated with NAA at 40 and $50 \mathrm{ppm}$ than the control in both seasons. While, total sugars content in fruits treated with NAA at 20 and $30 \mathrm{ppm}$ were statistically similar compared with untreated fruits in both season. Similar results were reported by Abd El-Ghaffar and Ceif ElRahman, (1986); El-Kassas, (1986) and Khalifa et al., (1984) on different date palm cultivars.

\section{Reducing Sugars:}

In both seasons, NAA at 40 and $50 \mathrm{ppm}$ significantly increased the reducing sugars content when compared with the untreated control. No significant pronounce effects when the fruits treated with NAA at 20 and $30 \mathrm{ppm}$ compared with the untreated fruits in both seasons. Similar findings were reported by (Abd ElGhaffar and Ceif El-Rahman, 1986; and Khalifa et al., 1984). Increases of sugar contents in treatments of thinning may be attributed to an internal adjustment mechanism that makes the remaining fruits capable to efficiently use assimilates and improve their chemical and physical qualities in reduced competitive environments (Ali-Dinar et al., 2002 and Hammam et al., 2002). 
Table 1. Effect of NAA with different concentration on yield and fruit quality on Zaghloul date palm cultivar during 2005 season

\begin{tabular}{lcccccc}
\hline \multirow{2}{*}{ Characteristics } & \multicolumn{9}{c}{ NAA Concentration (ppm) } & \multirow{2}{*}{ L.S.D.0.05 } \\
\cline { 2 - 5 } & Control & $\mathbf{2 0}$ & $\mathbf{3 0}$ & $\mathbf{4 0}$ & $\mathbf{5 0}$ & \\
\hline Fruit drop percentage (\%) & 31.58 & 33.80 & 37.37 & 38.12 & 40.53 & 4.15 \\
Bunch weight (Kg) & 18.17 & 17.38 & 16.75 & 16.13 & 15.55 & 2.09 \\
Fruit weight (gm) & 21.59 & 23.42 & 24.76 & 25.39 & 26.15 & 1.90 \\
Flesh weight (gm) & 19.41 & 20.98 & 22.71 & 23.13 & 23.85 & 2.05 \\
Fruit length (cm) & 5.61 & 5.75 & 5.78 & 5.82 & 5.99 & 0.18 \\
Fruit diameter (cm) & 2.64 & 2.78 & 2.84 & 2.83 & 2.92 & 0.21 \\
Dry matter content (\%) & 30.10 & 29.78 & 29.27 & 29.83 & 28.20 & 1.30 \\
T.S.S. (\%) & 19.90 & 20.57 & 21.57 & 23.00 & 23.74 & 3.02 \\
Total sugar (\%)* & 23.77 & 25.52 & 26.15 & 29.67 & 31.42 & 5.30 \\
Reducing sugar (\%)* & 13.39 & 15.35 & 16.95 & 19.90 & 21.21 & 4.07 \\
Titratable acidity & 0.120 & 0.118 & 0.113 & 0.111 & 0.109 & 0.009 \\
Tannins (\%) & 0.107 & 0.102 & 0.094 & 0.083 & 0.079 & 0.016 \\
\hline * & & & & & &
\end{tabular}

*On fresh weight base

Table 2. Effect of NAA with different concentration on yield and fruit quality on Zaghloul date palm cultivar during 2006 season

\begin{tabular}{|c|c|c|c|c|c|c|}
\hline \multirow{2}{*}{ Characteristics } & \multicolumn{5}{|c|}{ NAA Concentration (ppm) } & \multirow{2}{*}{ L.S.D. ${ }_{0.05}$} \\
\hline & Control & 20 & 30 & 40 & $\mathbf{5 0}$ & \\
\hline Fruit drop percentage (\%) & 23.48 & 25.75 & 27.32 & 30.35 & 34.42 & 3.77 \\
\hline Bunch weight $(\mathrm{Kg})$ & 21.30 & 20.48 & 19.92 & 18.77 & 18.55 & 2.05 \\
\hline Fruit weight (gm) & 19.41 & 20.43 & 22.93 & 24.15 & 24.92 & 3.27 \\
\hline Flesh weight (gm) & 17.30 & 18.27 & 20.81 & 22.00 & 22.75 & 3.11 \\
\hline Fruit length $(\mathrm{cm})$ & 5.44 & 5.60 & 5.69 & 5.76 & 5.86 & 0.20 \\
\hline Fruit diameter $(\mathrm{cm})$ & 2.54 & 2.68 & 2.73 & 2.75 & 2.85 & 0.17 \\
\hline Dry matter content (\%) & 26.33 & 26.28 & 26.07 & 25.51 & 25.77 & N.S \\
\hline T.S.S. (\%) & 18.67 & 19.80 & 20.34 & 22.00 & 22.34 & 2.57 \\
\hline Total sugar $(\%)^{*}$ & 21.52 & 23.82 & 23.76 & 24.72 & 26.82 & 3.18 \\
\hline Reducing sugar $(\%)^{*}$ & 11.39 & 12.87 & 12.85 & 14.74 & 16.00 & 2.99 \\
\hline Titratable acidity & 0.130 & 0.127 & 0.122 & 0.119 & 0.117 & 0.010 \\
\hline Tannins (\%) & 0.109 & 0.107 & 0.101 & 0.097 & 0.092 & 0.009 \\
\hline
\end{tabular}

*On fresh weight base

\section{Titratable acidity:}

NAA treatments had significantly effect on acidity content of date fruits. Significant lower of acidity content was observed in fruit treated with NAA at 40 and $50 \mathrm{ppm}$ than the untreated fruits in both seasons. On the other hand, the acidity content was similar statistically in fruits treated with NAA at 20 and $30 \mathrm{ppm}$ as well as untreated fruits in both seasons (Tables 1 and 2). Similar results were reported by (Abd El-Ghaffar and Cief El-Rahman, 1986).

\section{Tannins content:}

Naphthalene acetic acid treatment significantly affected the tannins content of treated fruits (Table 1 and 2 ). The data showed that significant reduction in tannins content was observed at 40 and 50 ppm NAA treatments than the control in both seasons. Tannins content in fruits treated with NAA at 20 and $30 \mathrm{ppm}$ were similar statistically compared with untreated fruits. These results are in agreement with those of El-Hammady et al., (1983) and Khalifa et al., (1984) on different date palm cultivars.

\section{CONCLUSION}

It can be generally concluded that NAA treatments at 40 and $50 \mathrm{ppm}$ were significantly superior to the other treatments in increasing fruit and flesh weights, fruit dimensions, T.S.S., total sugars and reducing sugars, while it decreased dry matter, acidity and tannins content in fruits. This may be due to the pronounced thinning effects of NAA treatments on reducing yield than the untreated treatment (control).

\section{REFERENCES}

Abd El-Gaffar, A. and S.F. Ceif El-Eahman (1986). Effect of different concentration of NAA on fruit Drop, yield and quality of date palm of Dhakki cultivar. Second Symposium on Date Palm. King Faisal Univ., Saudi Arabia.

Abou Rawash, M.A. and A. Moustafa (2007). Effect of naphthalene acetic acid spray on yield and fruit quality of 
"Seewy" dates. Proc. Of the Fourth Symposium on Date Palm in Saudi Arabia.

Ali-Dinar, H.M.; A.A. Alkhateeb; I. Al-Abdulhadi; A. Alkhateeb; K.A. Abugulia and G.R. Abdulla (2002). Bunch thinning improves yield and fruit quality of date palm (Phoenix dactylifera L.). Egypt J. Applied Sci., 17(11): 228-238.

Aljuburi, H.J., Hasan and H. Al-Masry (2003). The effects of plant growth regulators application on production and fruit characteristics of date palm trees. Proceedings of the International Conference on Date Palm El- Kassim Saud: Arab: :16-19 Sept. pp. 493-502.

Al-Obeed, R.S.; Harhash, M. and N.S. Fayez (2003). Effect of chemical thinning on yield and fruit quality of Succary date palm cultivar grown in Riyadh region. Proceedings of the International Conference on Date Palm EL-Kassim Saudi: Arabia: 16-19 Sept. pp. 725-738.

Al-Saikhan, M.S. (2008). Effect of thinning practices on fruit yield and quality of Ruzeiz date palm cultivar (Phoenix dactylifera L.) in Al-Ahsa Saudi Arabia. Asian Journal of Plant Sci. 7(1): 105-108.

Association of Official Agricultural Chemists (1995). Official Methods of Analysis, A.O.A.C.13 ${ }^{\text {th }}$ Ed. Published by A.O.A.C. Washington DC.

Bakr, E.I.; S. El-Kasary; A. El Banna and H.S. Ghazawy (2007). Effect of NAA on fruit setting, bunch weight and fruit characteristics of Samani and Zaghloul date palm cultivars. Proc. of the Fourth Symposium on date palm in Saudi Arabia 5-8 May.

El-Kassas, S. (1986). Effect of some growth regulators on the yield and fruit quality of Zaghloul date palm. Proc. of the Second Symposium on the Date Palm, King Faisal Univ., A;-Ahassa, Saudi Arabia, Vol. (1) 179-186.

El-Hammady, M.M., A.S. Khalifa and A.M. El-Hammady (1983). Fruit thinning in date palm with ethaphone.
Proceeding of $1^{\underline{\text { st }}}$ Symposium on Date Palm, Saudi Arabia, pp. 284-295.

Forse, W.T. (1938). Determination of sugar in plant materials; a photometric method Indus. Eng. Anal. Ed. 10: 411-418.

Hammam, M.S., A. Sabour and S. Ebeed, 2002. Effect of some fruit thinning treatments on yield and fruit quality of Zaghloul date palm. Arab Univ., J. Agric., Sci., 10(1): 261-271.

Hussein, F.; M.S. El-Kahtany and, Y.A Wally. (1979). Date cultivation and production in both Arab and Islamic nations. Egyptian Horticulture Society Ain Shams Press.

Hussien, M.A.; H.M. Mahmoud and K.A. Amin (1986). Effect of GA3 and some pollen application on fruit quality of Zaghloul dates. Abstract on the Second Symposium Date Palm. March 3-6, King Faisal Univ., Saudi Arabia.

Khalifa, A.S.; Z.H. Hamdy; H.M. El-Masry; M.R. Tadros, and G.A. Said (1984). Effect of some growth regulators on thinning "Amhat" Date Palm. Agric. Res. Revi. Vol. 62. No. 3 A P. 255-266.

Moustafa, A.A., S.A.Samir and A. I. Abou El-Azayem (1993). Date fruit response to naphthalene acetic acid. Proc. of the Third Symposioum on the Date Palm.

Smith, F.; M.A. Gilles; J.K. Hamilton and P. A. Gedeesi (1956). Colorimetric methods for determination of sugars and related substances. Anal. Chem., 28: 350-356.

Snedecor, G.W. and W.G.Cochran (1980). Statistical Methods Oxford and J.B.H. Publishing Co., $6^{\text {th }}$ edition

Tavakkoli, A., E. Tafazoli and M. Rahemi (2006). Comparison of hand versus chemical thinning on quality and quantity of fruits and alternate bearing of Shahani date (Phoenix dactylifers L.). International Conference on Date Palm Production and Processing Technology, Muscat, Oman, May, pp: 9-11.

Winton, A.L. and K. B. Winton (1958). The analysis of foods. John Wiley and Sons, Inc. London, P: 857. 


\section{الملخص العربي}

\section{تأثير الرش بالنفثالين ممض الحليك على الخصول وخصائص ثمار البلح الزغلول}

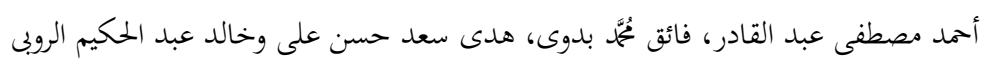

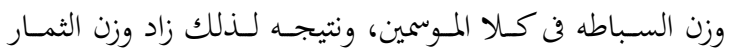
واللحم وأبعاد الثمره معنويا مقارنة بعدم الرش في كلا الموسمين. 3 أظظهرت النتائج زيادة معنويه في نسبة المواد الصلبه الذائبه ومتتوى

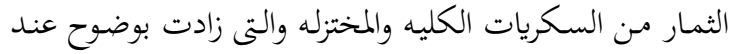

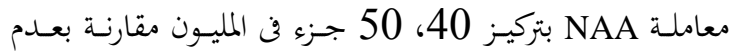

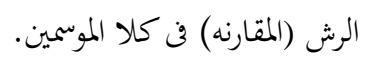

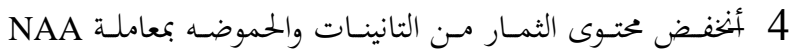

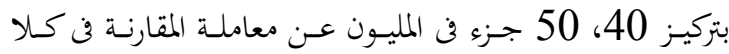

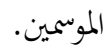

من هذه النتائج إتضح أن الفائده قد عادت من أستعمال NAA

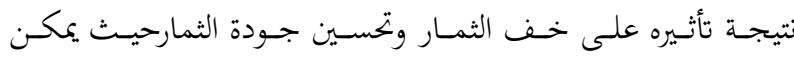
أستبدال الحف اليدوى بالحف الكيماوى بنظمات النمو NAA بتركيز

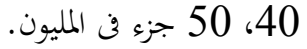

تم دراسة تأثير الحف الكيماوى للـNAA بتركيزات صفر ، 20،

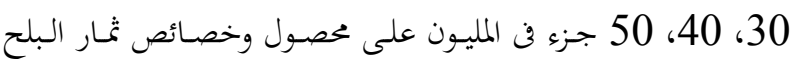
الزغلول خلال موسمى 2005، 2006 بمزرعة معطة بحوث البساتين بالقناطر الخيريه بمحافظة القليوبيه- مصر.

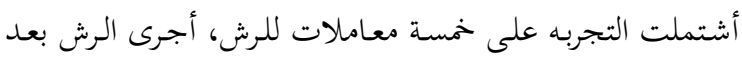
التلقيح بأسبوعين وقد رشت سباطات معاملة المقارنه بالماء وكانت أهم آترك النتائج التى تم الحصول عليها هي: 1 وتجـد أن الرش بـNAA أحسدث زياده في نسبة تساقط الثمار،

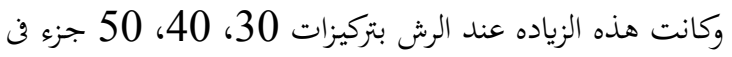
المليون على الترتيب بالمقارنه بعامله المقارنه. 2 تل وزن السباطه متأثره بععاملات الرش مقارنه بععاملة المقارنه. وقد

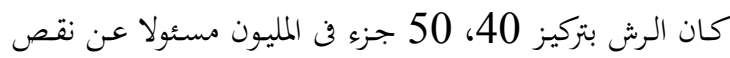

